\title{
GLUCANTIME RESISTANT LEISHMANIA PROMASTIGOTES ARE SENSITIVE TO PENTOSTAM
}

\author{
Elizabeth Spangler Andrade Moreira, Juliana Becattini Guerra and Maria de \\ Lourdes Petrillo-Peixoto
}

\begin{abstract}
Growth inhibition in vitro tests were used to study the susceptijility to pentostam of different Leishmania strains involved in cutaneous and mucocutaneos leishmaniasis - one glucantime sensitive strain, three naturally glucantime resistant strains and one glucantime resistant line developed by in vitro drug exposure. Contrasting with the high degree. of glucantime resistance, all strains were sensitive to pentostam. These differences suggest that there is some relationship between chemical structure and in vitro activity for these antimonial compounds. These data justify a clinical re-evaluation to compare therapeutic efficacy of glucantime and pentostam in the treatment of leishmaniasis.
\end{abstract}

Key-words: Leishmania Pentavalent antimonial compounds. Growth inhibition. Experimental chemotherapy.

Antimony-unresponsiveness in visceral and mucocutaneous leishmaniasis are increasing in severity and prevalence worldwide 5.6141719 . It is not known if antimonial drug insensitivity is attributable to inherent or developed resistance of the parasite, in addition to a variety of host factors that also contribute to chemotherapeutic relapse.

The pentavalent antimony (Sb) complexed to a carbohydrate in the form of sodium stibogluconate (pentostam) or meglumine antimoniate (glucantime) is the only antileishmanial chemotherapeutic agent with clearly favorable therapeutic index. Pentostam, produced in the United Kingdom, is used there, in USA and in most African and Midle-East countries; glucantime, produced in France and in Brazil, is used in frenchspeaking countries and in Latin America. Different dosage schedules have been recommended ${ }^{61314}$, considering the variation of treatment among the various forms of human leishmaniasis and the importance of the relapse problem. Generally, all

\footnotetext{
Departamento de Microbiologia, Instituto de Ciências Biológicas, Universidade Federal de Minas Gerais, Belo Horizonte, MG.

Research supported by PRPq/UFMG.

This work was performed in partial fulfillment of the requirements for the Ph.D. (E.S.A.M.) at Instituto de Microbiologia da Universidade Federal do Rio de Janeiro.

Address to: Dra. Elizabeth S.A. Moreira. Laboratório de Biologia de Microbiologia/ICB/UFMG, CP: 2486, 31271970 Belo Horizonte, MG

Recebido para publicação em 28/05/92.
}

drug doses are expressed in milligrams of Sb per kilogram per day and the therapeutic schemes are standardized irrespectively of the preparation ${ }^{312}$. On theoretical basis, it is assumed that both drugs have equivalent therapeutic indexes, i.e., the $\mathrm{Sb}$ in the two formulations are equally removable from the respective carbohydrates. There are no reports of clinical studies comparing the therapeutic effectiveness of glucantime and pentostam applied in the same dose $\mathrm{e}^{312}$.

Nevertheless, differences in the susceptibility between both drugs are observed, when glucantime is included in in vitro comparative tests for $\mathbf{S b}$ activity: usually pentostam is more active than glucantime $111{ }^{18}$. These studies indicate that Leishmania strains may have different susceptibility profiles for each drug, although no rationale for these variations is presented.

A re-evaluation of this problem is necessary since pentavalent antimonials remain the drugs of choice for leishmaniasis. Here, we report that promastigotes of glucantime resistant Leishmania strains, involved in cutaneous and mucocutaneous leishmaniasis, are sensitive to pentostam, when tested under identical conditions.

\section{MATERIAL AND METHODS}

The Leishmania (V.) braziliensis, strains MHOM/BR/75/M2903, MHOM/BR/??/LTB259, 
Moreira ESA, Guerra JB, Petrillo-Peixoto ML. Glucantime resistant Leishmania promastigotes are sensitive to pentostam. Revista da Sociedade Brasileira de Medicina Tropical 25:247-250, out-dez, 1992.

ISQN/BR/85/M9947 and the Leishmania (L.) amazonensis IFLA/BR/86/M10995 were used in these experiments. With the exception of the M2903, all strains were previously shown to be resistant to glucantime ${ }^{16}$. A glucantime-resistant line (R2-1) derived from the sensitive $L$. (V.) guyanensis IUMB/ $\mathrm{BR} / 85 / \mathrm{M} 9945$ strain, obtained by in vitro drug exposure to high glucantime concentration ${ }^{15}$, was also evaluated. The strains have been cryopreserved as well as maintained by serial passage in logarithmic phase at $25^{\circ} \mathrm{C}$ in a liquid complex medium supplement with $40 \%$ of whole rabbit blood ${ }^{10}$.

Glucantime (meglumine antimoniate, $85 \mathrm{mg} \mathrm{Sb}$ $\mathrm{ml}^{-1}$, batch 020, Rhodia SA, Brazil) and pentostam (sodium stibogluconate, $100 \mathrm{mg} \mathrm{Sb} \mathrm{ml}^{-1}$, bacth C54262, WellcomeFoundation Ltd, England) were stored in the dark, at room temperature. Fresh drug samples were used in each experiment. The concentration of these drugs is given as $\mathrm{mg}$ of pentavalent antimony according to the manufactures' information.

The sensitivities of different Leishmania strains to both antimonial drugs, based on promastigotes growth inhibition, were determined as previously described ${ }^{16}$. Briefly, $25 \times 10^{5}$ parasites in $5.0 \mathrm{ml}$ of fresh medium were incubated with different concentrations of the drug (pentostam or glucantime). Cultures of each Leishmania strains lacking drug were maintained in parallel as control. The number of parasites was determined by counting in a Coulter Counter (Model D2) and all results were expressed as the mean of at least two experiments in duplicate. The effect of drug on cell yield was expressed as the percentage of cell number related to control cultures at late log phase.

\section{RESULTS AND DISCUSSION}

In previous studies ${ }^{16}$ we demonstrated that the M9947, M10995 and LTB259 Leishmania strains are naturally resistant to glucantime: no significative growth effect could be observed in presence of glucantime concentration below $2.0 \mathrm{mg} \mathrm{Sb} / \mathrm{ml}$ - a drug concentration which showed high growth inhibition of sensitive cells. The response of different strains to pentostam and glucantime in the present comparative study is summarized in Table 1. The data show that these strains are sensitive to pentostam. Even in the case of M10995 strain, the
Table 1 - Susceptibility of different Leishmania strains to antimonial drugs.

\begin{tabular}{crrrrr}
\hline \multirow{2}{*}{$\begin{array}{c}\text { Drug } \\
\text { (mg Sb/ml) }\end{array}$} & \multicolumn{5}{c}{ Promastigote survival* } \\
\cline { 2 - 6 } & M2903 & M9947 & LTB259 & R2-1 & M10995 \\
\hline Pentostam & & & & & \\
0.25 & 4 & 12 & 15 & 9 & 84 \\
0.50 & 2 & 6 & 13 & 7 & 55 \\
1.00 & 2 & 7 & 12 & 6 & 37 \\
Glucantime & & & & & \\
2.00 & 5 & 78 & 63 & 73 & 98 \\
\hline
\end{tabular}

* Percent of growth at drug concentration (mg Sb/ml) related to the control cell number at late log phase.

dose of pentostam which gave rise to about $50 \%$ in growth inhibition was one fourth of that of glucantime used without response. Furthermore, a cell line derived from $L$. (V.) guyanensis, selected in laboratory for glucantime resistance, showed very little response to $2 \mathrm{mg} \mathrm{Sb} / \mathrm{ml}$ in the form of glucantime, whereas a high growth inhibition was observed in the presence of pentostam, even at lowest concentration tested $(0.25 \mathrm{mg} \mathrm{Sb} / \mathrm{ml})$.

These data are simultaneously disturbing and exciting. They may suggest that there is indeed some relation between chemical structure and in vitro activity for these antimonial compounds. Sinceglucantime and pentostam chemical structures and their biochemical mechanisms of antileishmanial activity are unknown it can be proposed that the two compounds may have different mechanisms of action. On the other hand, the influence of carbohydrate moiety on antimony activity demonstrated when the leishmanicidal effects of antimony coupled to yeast mannan were compared to those obtained with glucantime ${ }^{2}$ may suggest that a differential kinetics of drug accumulation and $\mathrm{Sb}$ release could account for the differences observed. Unfortunately, radiolabeled pentostam and glucantime necessary to evaluate the capacity of cells to transport the drugs is commercially unavailable.

Another possibly explanation should consider that Leishmania, as other parasites, has the potential to respond to drug pressure in multiple ways, resulting in drug resistance ${ }^{4}$. So, the different drug susceptibility profiles observed between pentostam and glucantime may involve different mechanisms of resistance. Drug resistance in Leishmania has 
Moreira ESA, Guerra JB, Petrillo-Peixoto ML. Glucantime resistant Leishmania promastigotes are sensitive to pentostam. Revista da Sociedade Brasileira de Medicina Tropical 25:247-250, out-dez, 1992.

been studied with some drugs ${ }^{4}$ but only few studies have been done with antimonial compounds 71118 and very little is known about the mechanisms of antimonial resistance.

Although drug sensitivity data obtained with promastigotes in vitro cannot be directly extrapolated to the situation in vitro, these results justify a clinical evaluation in cutaneous and mucocutaneous leishmaniasis, once very seldom pentostam is considered as an alternative after glucantime failure ${ }^{9}$.

\section{RESUMO}

Diferentes amostras de Leishmania foram analisadas quanto à susceptibilidade in vitro ao pentostam - uma cepa de L. (V) braziliensis considerada sensivel ao glucantime, três cepas (duas L. (V) braziliensis e uma L. (L) amazonensis) consideradas naturalmente resistentes ao glucantime, uma linhagem resistente (L. (V) guyanensis) selecionada in vitro pela exposiçao em alta concentração de droga. A elevada sensibilidade destas amo tras em contraposição à resistência observada para o glucantime sugere existir relação entre a estrutura química $e$ a atividade destes compostos. Estes dados indicam a necessidade de uma avaliação comparativa de atividade clínica do pentostam e do glucantime no tratamento da leishmaniose.

Palavras-chaves: Leishmania. compostos antimoniais pentavalentes. Inibição de crescimento. Infecção experimental.

\section{ACKNOWLEDGMENTS}

We thank Drs P. D. Marsden, Universidade de Brasilia, and R. Lainson, Instituto Evandro Chagas, Belém, for providing strains of Leishmania, and to A. L. Miranda Vilella for provinding the glucantime resistant cell line. The technical support of M.A. Santos is gratefully acknowledged.

\section{REFERENCES}

1. Allen S. Neal RA. The in vitro susceptibility of macrophages infected with amastigotes of Leishmania spp to pentavalent antimonial drugs and other compounds with special relevance to cutaneous isolates. In: Leishmaniasis Hart D T (ed) Plenum Publishing Corporation p.711-720, 1989.

2. Barbieri CL, Figueiredo EN, Gorin PAS, Travassos LR. The effect of mannan-coupled antimony on Leishmania infected macrophages. Memórias do
Instituto Oswaldo Cruz 85 (suppl.I):103, 1990.

3. Berman JD, Chemotherapy for leishmaniasis: biochemical mechanisms, clinical efficacy, and future strategies. Reviews of Infectious Diseases 10:560$586,1988$.

4. Beverley SM. Gene amplification in Leishmania. Annual Review of Microbiology 45:417-444, 1991.

5. Bryceson ADM, Chulay JD, Ho M, Mugambii M, Were JB, Muigai K, Chunge C, Gachihi G, Meme J, Anabwani G, Bhatt SM. Visceral leismaniasis unresponsive to antimonial drugs. I-clinical immunological studies. Transactions Royal Society of Tropical Medicine and Hygiene 79:699-704, 1985.

6. Bryceson ADM, Chulay JD, Mugambii M, Were JB, Gachihi G, Chunge C, Muigai R, Bhatt SM, Ho $M$, Spencer HC, Meme J, Anabwani G. Visceral leismaniasis unresponsive to antimonial drugs. IIResponse to high dosage sodium stibogluconate or prolonged treatment with pentamidine. Transactions Royal Society of Tropical Medicine and Hygiene 79:705-714, 1985.

7. Callahan HL, Beverley SM. Heavy metal resistance: a new role for P-glycoproteins in Leishmania. The Journal of Biological Chemistry 266:18427-18430, 1991.

8. Costa JML. Marsden PD. Low dose glucantime therapy in Leishmania viannia braziliensis (Lvb) infections. Revista da Sociedade Brasileira de Medicina Tropical 21:85-86, 1988.

9. Dietze R, Araújo RC, Lima MLR, Vexenat JA, Marsden PD, Barreto AC. Ensaio terapêutico com glucantime em sagüis (Callithrix jacchus) infectados com uma cepa de Leishmania donovani aparentemente resistente ao tratamento. Revista da Sociedade Brasileira de Medicina Tropical 18:39$42,1985$.

10. Figueiredo Y, Costa CA, Mayrink W, Araújo FG, Dias M, Melo MN, Magalhães P, Willians P, Batista SM, Coelho MV. Nutrição e metabolismo de formas de cultura de Leishmania. Revista do Instituto de Medicina Tropical de São Paulo 18:306-314, 1976.

11. Grogl M, Oduola AMJ, Cordero LDC, Kyle DE. Leishmania spp: development of pentostam-resistant clones in vitro by discontinuous drug exposure. Experimental Parasitology 69:78-90, 1989.

12. Marsden PD. New light on pentavalent antimonials in the treatment of leishmaniasis. Revista da Sociedade Brasileira de Medicina Tropical 16:172174, 1983.

13. Marsden PD. Pentavalent antimonials: Old drugs for new diseases. Revista da Sociedade Brasileira de Medicina Tropical 18:187-198, 1985.

14. Marsden PD, Sampaio RNR, Carvalho EM, Veiga JPT, Costa JLM, Llanos-Cuentas EA. High 
Moreira ESA, Guerra JB, Petrillo-Peixoto ML. Glucantime resistant Leishmania promastigotes are sensitive to pentostam. Revista da Sociedade Brasileira de Medicina Tropical 25:247-250, out-dez, 1992.

continuous antimony therapy in two patients with unresponsive mucosal leishmaniasis. American Journal of Tropical Medicine and Hygiene 34:710$713,1985$.

15. Miranda-Vilela AL. Aspectos genéticos da resistência ao antimoniato de $\mathrm{N}$-metilglucamina (glucantime) em formas promastigotas de Leishmania. Tese de mestrado. Universidade Federal de Minas Gerais, Minas Gerais, 1991.

16. Moreira ESA, Petrillo-Peixoto ML. In vitro activity of meglumine antimoniate, a pentavalent antimonial drug, on Leishmania promastigotes. The Brazilian Journal of Medical and Biological Research 24:459-
469, 1991.

17. Rocha RAA, Sampaio RN, Guerra M, Magalhães A, Cuba CC, Barreto AC, Marsden PD. Apparent glucantime failure in five patients with mucocutaneous leismaniasis. Journal of Tropical Medicine and Hygiene 83:131-139, 1980.

18. Ullman B, Carrero-Valenzuela E, Coons T. Leishmania donovani: isolation and characterization of sodium stiboglucanate (Pentostam)-resistant cell lines. Experimental Parasitology 69:157-163, 1989.

19. Verdejo J, Alvar J, Polo RM, Gonzales-Lahoz JM. Glucantime-resitant visceral leishmaniasis in immunocompromissed patients. The American Journal of Medicine 8:128, 1988. 